\title{
Books Briefly Noted ${ }^{\star}$
}

Complementing Museum Anthropology Review's "Book Reviews" section, "Books Briefly Noted" offers non-evaluative overviews of recent books in the fields of museum anthropology and interdisciplinary material culture studies.

\section{Religious Objects in Museums: Private Lives and Public Duties. Crispin Paine. London: Bloomsbury Academic, 2013. 144 pp.}

Crispin Paine's roles as a museums and heritage consultant and editor of Material Religion inform this exploration of intersections between religion and museums. The chapter titles outline his main points about religious objects, particularly those in museums: Objects curated, Objects visited, Objects worshipped and worshipping, Objects claimed, Objects respected, Objects demanding and dangerous, Objects elevating, Objects militant, Objects promotional, and Objects explanatory and evidential. Although lengthier chapter subtitles clarify his meanings (Chapter 8, Objects militant: How religious objects are converted and fight for their new masters), the short titles succinctly evoke Paine's arguments about the types and roles of religious objects and people in museums. Discussions of religious representation have been more prevalent in museum literature than considerations of religious practice, so it is notable that this book addresses both. To illustrate several of his primary points, the author has included 21 high-quality black-andwhite images of religious objects, museums, and people interacting with objects in museum spaces, each of which is accompanied by a somewhat lengthy caption that identifies it and explains its relevance. Notes: 6 pp. References: 12 pp. Index: 8 pp. [SGI]

\section{The Ethics of Sightseeing. Dean MacCannell. Berkeley: University of California Press. 2011. $271 \mathrm{pp}$.}

Since the 1970s, Dean MacCannell's work has been instrumental in shaping the field of tourism studies. In this current book, MacCannell explores the ethical dimensions of sightseeing (as one aspect of the broader category of tourism), suggesting that "ethical considerations" (ix) have been lacking from the study of sightseeing practices and "the social organization and cultural setup of attractions" (x). The book is made up of four parts containing a total of thirteen relatively brief chapters. In his explorations of a wide range of tourist sites and contexts, MacCannell draws on a variety of cultural theories and theorists, including Goffman, Lacan, Barthes, Foucault and Lévi-Strauss. He notes that his own methodology is not standard, but could be described as "nonsystematic naturalistic observation combined with scholarship" (x). In one section, MacCannell revisits and updates his famous concept of "staged authenticity." Throughout the text he includes sidebars with personal anecdotes illustrating specific incidents

\footnotetext{
* These editorially reviewed contributions were accepted for publication in Museum Anthropology Review between January 1 and June 1, 2014. The work is licensed under the Creative Commons Attribution 4.0 International License. To view a copy of this license, visit $h t \mathrm{ttp} / /$ creativecommons.org/licenses/by/4.0/. Contributors to this compilation are Suzanne Godby Ingalsbe [SGI], Michael Dylan Foster [MDF], Flory Gingging [FG], Gloria M. Colom-Brana [GMCB], Teri Christine Klassen [TCK], and Kate Schramm [KS].
} 
and influences that have informed his own research through the years. Includes 21 illustrations. Notes (including references): 23 pages. [MDF]

\section{Nini Towok's Spinning Wheel: Cloth and the Cycle of Life in Kerek, Java. Rens Heringa. Los Angeles: Fowler Museum at UCLA. 2010. 92 pp.}

This work by textile scholar Rens Heringa focuses on the rural community of Kerek, the only place in Java where batik is still made on locally handwoven cotton cloth. In Kerek, every cloth that is created for use serves a distinct purpose (e.g., to be worn by individuals of a particular social group), and its functions, techniques, design, and color combinations comprise part of "a highly structured and elaborate system of knowledge that is remarkably integrated with the community's social organization, mythology, and ritual practices" (10). Tied to a Fowler Museum exhibition, this book addresses such topics as the specializations of Kerek's hamlets; the dress choices that individuals might make based on their age, gender, or social position; the design format of Kerek's cloths; the relationship between socio-economic status and textile techniques; color in Kerek batiks; and the myth of Nini Towok, the Javanese goddess whose "moonbeams" are believed to provide the foundation for Kerek's textile system and its meanings. This work, the ninth title in the Fowler Museum's Textile Series, contains 110 color illustrations, over 60 of them cataloged batik samples. Glossary: 2 pp. [FG]

\section{Weavers' Stories from Island Southeast Asia. Roy W. Hamilton, with contributions by Jill Forshee, Traude Gavin, and Cherubim A. Quizon. Los Angeles: Fowler Museum at UCLA. $2012.88 \mathrm{pp}$.}

In this book, Roy W. Hamilton, senior curator for Asian and Pacific Collections at the Fowler Museum at UCLA, profiles ten women weavers and batik artists from Indonesia, Malaysia, the Philippines, and Timor Leste. Like the Fowler Museum exhibition to which it is linked, the primary focus of this work is the women's personal stories, their individual connections to their art challenging the popular notion that "weaving and batik making are 'crafts' as opposed to 'fine arts' and that as such they are the product of anonymous craftspersons rather than nameable artists" (9). The stories in this book touch on such themes as the women's sources of creative inspiration, their religious beliefs, their social and economic circumstances, their family life, and their engagements with modernity. The tenth volume in the Fowler Museum's Textile Series, this work is richly illustrated with 78 color photographs of the artists and of their cloths. It also includes a DVD containing short videos of the women working and narrating their personal stories. References Cited: 1 p. [FG]

\section{An Anthropology of Architecture. Victor Buchli. London: Bloomsbury, 2013. 211 pp.}

This book takes into account architecture's societal role throughout history and across different cultures, from the ancient past to contemporary architectural theory. Victor Buchli draws from his work with material culture, providing a comprehensive introduction to the study of 
architecture within the context of anthropological studies. The first chapter sets up architecture as a subject of interest to the field of anthropology during the "long nineteenth century," contextualizing architecture's original popularity of research, eventual decline and subsequent reemergence during the mid-twentieth century. Buchli then uses various theoretical approaches to architecture including the home as a performative space within the context of Levi-Strauss' concept of "house societies," architecture as potential ethnographic data source for archaeologists, and the continual reconstruction of spatial concepts within changing societies. The decay and destruction of architecture is proposed as an integral component of a building's lifecycle with as much significance as its conservation. The book is illustrated using black and white illustrations and photographs in order to reference the historic concepts and existing places being described. Notes: 1 page. Bibliography: 13 pages. [GMCB]

\section{The Peruvian Four-Selvaged Cloth: Ancient Threads/New Directions. Elena Phipps. Los Angeles: Fowler Museum at UCLA. 2013. 96 pp.}

This book is the catalogue for an exhibition that ran from October 2013 to February 2014 at the Fowler Museum in Los Angeles. Part One presents examples of cloth that was woven with all four sides finished ("four-selvaged") in Peru during the period from 500 to $100 \mathrm{BCE}$ and during the Inca empire (1485-1532). Part II, "New Directions: The Four-Selvaged Cloth Today," presents woven works by contemporary artists (Sheila Hicks and Jim Bassler) who are influenced by the ancient weavers. Also included are John Cohen's black-and-white photographs of Peruvian women at various stages of cloth making, dating mostly to the 1950s; and contemporary images of the Peruvian highlands by author Elena Phipps and Yutaka Yoshii. Phipps, a retired conservator from the Metropolitan Museum of Art, curated the exhibition. Ancient items pictured include panels, tunics, and bands, with motifs of corn plants, cotton plants, birds, crowned figures carrying staffs, warriors, crayfish, and large supernatural figures; also a burial face mask, practice sampler, coca bags, needle case, several fragments with diverse intricate designs, and tunics with fringe. Notes and Bibliography: 2 pp. [TCK]

\section{Body Style. Therèsa M. Winge. London: Berg. 2012. 160 pp.}

Noting that subcultures have flourished in Western culture since World War II, Therèsa M. Winge posits "body style," including dress, tattoo, and piercing, as a means of nonverbal communication and "a site for understanding the unique context of subcultural identity, resistance, agency, and style" (7). She finds that "current subculture body style results from postmodern and globalized cultures" (90), and argues, "In the past few decades, subcultures stimulated a bodily awareness - the body renaissance - in Western culture, highlighting the importance of subcultural identities that confront and test the understood social and cultural conventions and norms of aesthetics, gender, and spirituality" (111). She discusses the history of "subculture" as a concept, dating to Ralph Linton's The Study of Man (1936), and draws extensively on her work with North American Urban Tribal movement subjects. She perceives a "cyclical" relationship between mainstream and subculture: "The subculture is referencing the mainstream culture, albeit subversively, and the mainstream culture is referencing the subculture, usually in style (fashion) only" (91). Additional titles in Berg's Subcultural Series are Punk Style, 
Queer Style, and Fetish Style. Notes: 4 pp. Further Readings and References: 13 pp. Index: 2 pp. [TCK]

\section{Archaeology and Apprenticeship: Body Knowledge, Identity, and Communities of Practice. Willeke Wendrich, ed. Tucson: University of Arizona Press. 2012. 264 pp.}

Essays in this edited volume offer approaches to studying apprenticeship, "defined as the transmission of culture through a formal or informal teacher-pupil relation," drawing primary data from ancient and contemporary societies in diverse locations (2). Methods include: ethnography (northern Cameroon, New Mexican pueblos); a motor-performance experiment (University of Toronto undergraduates); use of "living craft [carpentry] traditions" to interpret archaeological timber remains (Norway) (61); a combination of ethnography and material remains (Australian Aborigines, hunter-gatherer groups); material remains (Palaeo Eskimos of Arctic Canada; ancient Egypt; ancient Urkesh [northeastern Syria]); and a combination of material remains, written records, and ethnography (ancient Greece). Additional chapters are: "Types of Learning in Apprenticeship," by Heather M.-L. Miller; and "Writing Craftsmanship? Vocabularies and Notation Systems in the Transmission of Craft Knowledge" (Scandinavia), by Lise Bender Jørgensen. Editor Willeke Wendrich writes in the conclusion, "Recognizing Knowledge Transfer in the Archaeological Record," that the book adds to the "collection of approaches to study the archaeological traces, focusing on learning practices, knowledge sharing, and the resulting cultural transmission within a community of practice" (259). Notes and References: about 43 pp. Index: 8 pp. [TCK]

\section{The Painted King: Art, Activism, and Authenticity in Hawai'i. Glenn Wharton. Honolulu: University of Hawai'i. 2012. 216 pp.}

This book is art conservator Glenn Wharton's first-person account of a collaborative "community-based" conservation project that contrasts with the art-historical conservation approach that prioritizes the artist's intent. In this case, out-of-state funding allowed local interests working with Wharton to proceed without state support. Located in a small Hawaiian town, Kapa'au, the conservation object is a European-made (1879) cast-brass public sculpture of Hawai'ian Islands King Kamehameha I (c. 1758-1819). Sculptor Thomas Ridgeway Gould (1818-1881) gave him both neoclassical and Native Hawaiian features. Area residents incorporate local meanings with expert information in making decisions such as whether to "gold-leaf the garments," as Gould intended, or "follow the local 'tradition' and continue painting the figure" (168). "Within a heterogeneous demographic setting, people struggled to come to terms with a culturally hybrid sculpture in ways their own backgrounds did not predict" (168). Some gained "experience and confidence to take civic action on issues such as unplanned development" (166). Community-based conservation "is about finding value in an active process of exploring versions of the past and analyzing the power dynamics in deciding what the past should look like" (174). Notes: 6 pp. Bibliography: 8 pp. Index: 11 pp. [TCK] 
Order and Disorder: Alighiero Boetti by Afghan Women. Christopher G. Bennett, Roy W. Hamilton, Alma Ruiz, and Randi Malkin Steinberger. Los Angeles: Fowler Museum at UCLA. 2012. $132 \mathrm{pp}$.

This book accompanied an exhibition that expanded the Fowler Museum's focus on "traditionbased arts from around the world" to include "dynamic intersections between the traditional and the modern or the contemporary" (7). It presents textile works that Italian artist Alighiero Boetti (1940-1994) designed, with features such as maps, flags, Italian and Dari words, and collage-like arrangements; but that anonymous Afghan women and girls who never met him embroidered between 1971 and 1994, often making color choices (98). Says Randi Malkin Steinberger in a transcribed interview, "That's what excited him, to see the many different ways in which people could interpret or follow his rules" (104). Included here are: Steinberger's photographs of the embroiderers at a Pakistan refugee camp, and vernacular Afghanistan-area embroidered textiles from ca. 1900-1986. Essays address embroidery in Afghanistan and Boetti in art historical context. Art historian Christopher G. Bennett notes Boetti's "interest in blurring conventional distinctions between 'high art' and craft" (55), that his mother had had an embroidery business, and that he paid his embroiderers "much more than the standard wage for such work" (59-60). Notes: about 2 pp. Boetti exhibitions and publications: 3 pp. References Cited: 1 p. [TCK]

From the Hands of a Weaver: Olympic Peninsula Basketry through Time. Jacilee Wray, ed. Norman: University of Oklahoma Press. 2012. 304 pp.

This edited volume presents essays on diverse aspects of the basket-making tradition that has evolved over 3,000 years among Native American groups on western Washington's Olympic Peninsula. Editor Jacilee Wray is an anthropologist at Olympic National Park. Chapters address: basketry as an undervalued art form; basketry as a commodity ("Marketing Olympic Peninsula Basketry and the Indian Arts and Crafts Act"); basketry traditions of particular tribal groups (Klallam, Twana, Quinault, Hoh, Quileute, Makah); ancient basketry of the peninsula, from about 3,000 years ago to $1700 \mathrm{AD}$ (including burden baskets such as for carrying fish, wood, and berries; and pack baskets, cradle baskets, tumplines, a whale harpoon flat bag, knob-topped conical hats, storage baskets, capes, and skirts; and mats used as shelter walls, mattresses, and canoe covers); contemporary threats to important basketry supplies (beargrass and sweetgrass); and memories of contemporary tribal basket-weavers ("Basketry Today"). There are 159 blackand-white photographs and drawings (archival and contemporary). Appendixes address "Basket Construction Techniques" and "Pre-1960s Basket Weavers" (about 280 listed, born as early as 1801). Bibliography (including newspaper articles and archival sources): $19 \mathrm{pp}$. Index: $15 \mathrm{pp}$. [TCK]

Dream Catchers: Legend, Lore and Artifacts. Cath Oberholtzer. Richmond Hill, Ontario: Firefly Books Ltd. 2012. 144 pp.

In this general-audience book, anthropologist Cath Oberholtzer provides historical and scholarly context for the popular culture phenomenon of the dream catcher. The sections in Part 1, "Legend and Distribution," are: Origins, Algonquian Cultures, and Dreaming. Part 2, "Net 
Charms," focuses on the object as a material culture form. Its sections are: Power in Lines and Knots, Non-Algonquian Cultures, and Dream Catchers Today. Part 3, "Scale," examines the dream catcher's move to popular culture. Sections are: Fascination with "Indians," Marketing, Artists and Manufacturers, and The Future. Illustrations include about 30 color photographs of dream catcher art works by contemporary sculptor Nick Huard, images of objects in several archival collections, and photos from stock photography agencies. Many statements in the text are not specifically attributed. Bibliography: 7 pp. Photo Credits: 2 pp. Index: 4 pp. [TCK]

\section{Elevating Western American Art: Developing an Institute in the Cultural Capital of the Rockies. Thomas Brent Smith, ed. Denver: Denver Art Museum, 2012. 320 pp. [Distributed by the University of Oklahoma Press.]}

This art historical book is a special 10th-anniversary edition of the annual publication of the Denver Art Museum's Petrie Institute of Western American Art, Western Passages (the museum was established in 1918). Marlene Chambers, who was the museum's director of publications for 30 years, wrote the first part, "A History of Western American Art at the Denver Art Museum." Editor Thomas Brent Smith, the institute's director, notes that she gives "particular attention...to the museum staff's efforts to become the leader in the study of western American art" (13). The 30 essays that follow, including many by past and present Denver Art Museum staff, "highlight and contextualize" western American works in the museum's collections (13). Section headings are: Landscapes, Contemporary Works, Trappers and Cowboys, Native America, and The Southwest. Smith notes that the essays draw not only from the institute collection but also from works in other museum departments: Native American; Photography; Spanish Colonial; Architecture, Design, and Graphics; and Modern and Contemporary Art. There are 300 color illustrations, many of them full-page. Notes accompany each article. [TCK]

\section{Iroquois Art, Power, and History. Neal B. Keating. Norman: University of Oklahoma Press. 2012. 360 pp.}

Author Neal B. Keating finds connections between past and present artworks of Iroquoian (or Haudenosaunee) people, using ethnohistorical and ethnographic methods and considering relations between speech, action, and visual expression. He places about half of the current Iroquois population of 75,000 to 100,000 in tribal territories in New York, Ontario, and Quebec; and most others elsewhere in cities (18). Book sections address: "the era of autonomy," predating European settlement; the colonial period (1535-1800) of displacement and loss of "native autonomy and self-determination" (12); the neocolonial era (1800-1950), when Canadian and US governments promoted "extermination of indigenous peoples;" and the decolonizing era (1950early 2000s) of "indigenous political struggles aimed at securing human rights," "marked by the recovery of self and of self-determination" (12). Keating finds "shifts in visual strategies that appear to correspond with broader structural changes," and emphasizes "sociocultural processes through which pictures mediate and reflect power relations" $(12,21)$. Color plates: 26 pp. (1600s-1940); 46 pp. (1973-2007, featuring "artists whose work most directly engages with the decolonization of consciousness" [14]). Notes: 10 pp. References: 18 pp. Index: 10 pp. [TCK] 
Races of Mankind: The Sculptures of Malvina Hoffman. Marianne Kinkel. Urbana: University of Illinois Press. 2011. 292 pp.

In this book, art historian Marianne Kinkel traces meanings of the "Races of Mankind" sculptures from 1933, when they "represented racial types artistically" at the Field Museum of Natural History at the Chicago World's Fair (3), to the early 2000s. Chapters address: racial theories that curators considered in planning the exhibition; Malvina Hoffman's role as sculptor; how Hoffman's studio and museum staff blended art and physical anthropology in producing the 91 bronze and stone pieces; explanations of race at the exhibition opening; how small-scale replicas were commodified and "linked to the Parisian artistic avant-garde" at a November 1933 exhibition in France (19); the use of small-scale replicas to evoke "the Christian ideal of a Brotherhood of Man" at a 1942 New York fundraiser for French relief societies (146); the dismantling of the museum exhibition in 1969 as the social climate rejected racial stereotypes; and the museum's loan of 11 "full-size plaster replicas" of African figures with black (but none of those with white) features for display at Chicago's Malcolm X College from 1971 to 2003 (191-194). Notes: 42 pp. Bibliography: 16 pp. Index: 14 pp. [TCK]

\section{Collecting Across Cultures: Material Exchanges in the Early Modern Atlantic World. Daniela Bleichmar and Peter C. Mancall, eds. Philadelphia: University of Pennsylvania Press. 2011. 392 pp.}

In this book, the history of collecting as a field (which emerged about 1985) is expanded from the early modern period (late 1400s to about 1800) in Europe to other parts of the world and the 19th century. "There is no doubt that collecting was a global phenomenon in the early modern era. The obsessions of collectors were most evident in the encounter between the Old World and the New," write the editors (7). For instance, contributor Sarah Benson finds, "The ability to acquire and control valuable foreign objects was a mark of royal power for a Siamese king [Phra Narai, in the late 1600s]" (174). Contributor Megan E. O'Neil's study of two albums that French people made in the latter 1800s based on their time in Mexico shows that this medium served as a "paper museum" (10). Essays show the common role of monarchs as collectors, the propensity of travelers to display aspects of their travels upon their return home, the role of mass production and commodification in distributing cross-media representations of the exotic, and the role of collecting practices in the emergence of anthropology and archaeology. Notes: 49 pp. Index: 19 pp. [TCK]

Burst of Breath: Indigenous Ritual Wind Instruments in Lowland South America. Jonathan D. Hill and Jean-Pierre Chaumeil, eds. Lincoln: University of Nebraska. 2011. 440 pp.

In this edited volume, anthropologists from South America, Europe, and the United States examine social and ritual uses of musical instruments among indigenous groups in central and northern South America. Following the introduction, there are six chapters in the section called "Natural Sounds, Wind Instruments, and Social Communication," then seven chapters in the 
section called "Musical Transpositions of Social Relations" (including Stephanie W. Alemán's "From Flutes to Boom Boxes: Musical Symbolism and Change among the Waiwai of Southern Guyana"). There are two chapters in the concluding section, "Historical and Comparative Perspectives," including Claudia Augustat's, "Sacred Musical Instruments in Museums: Are They Sacred?" Some essays note the use of instruments and music-making as a distinctive element of male identity. "Among the Amerindian peoples of the three Americas, women do not play any aerophones, apart from the exceptions that prove the rule, such as the Jalq'a of the southern Andes," writes Jean-Michel Beaudet (translated by Marc Brightman) in the final chapter, "Mystery Instruments." Notes and References Cited: about 65 pp. Index: 34 pp. [TCK]

\section{Lost in Translation: Rethinking Hopi Katsina Tithu and Museum Language Systems. Rachel E. Maxson, Chip Colwell-Chanthaphonh, and Lee Wayne Lomayestewa. Denver Museum of Nature and Science Annals, 2. Denver, CO: Denver Museum of Nature and Science, 2011. 139 pp.}

Using as an example a museum collection of Hopi and Zuni "katsina tithu" (known as "kachina dolls" in Western popular culture), this study models the potential for museums to enrich the documentation of their collections by using the language of source communities as a resource. In this case, sources beyond the existing museum catalogue included a Hopi cultural advisor and the Hopi Dictionary as well as early ethnographies. The authors recommend, "Linguists and curators should work together more closely.... This type of cooperation can feed language revitalization and increase cultural sensitivity by indigenizing the discourse on Hopi culture, material or otherwise" (44). The volume includes a database of katsina tithu names and spellings, definitions, and tribe and ceremony associations (46 pages); and a "plates section" with color images of all of the katsina tithu in the museum's collection that are judged appropriate for public viewing (about 140). Literature Cited: about 4 pp. [TCK]

To Capture the Sun: Gold of Ancient Panama. Richard G. Cooke, John W. Hoopes, Jeffrey Quilter, and Nicholas J. Saunders. Norman: University of Oklahoma Press, 2011. 160 pp.

This catalogue accompanied an exhibition at Tulsa's Gilcrease Museum of gold artifacts from ancient (200-1520 CE) Panama. The first essay provides historical context for the period when Spain was taking gold from the New World, mainly 1500-1550. "By the second half of the 16th century, although some gold continued to be extracted at great cost, the flashy ornaments... had been taken, and most had been melted down for bullion to pay Spanish debts," writes John W. Hoopes (41). A second essay examines "Metallurgy in Ancient America." A third considers the meanings of the gold pieces in their cultures of origin, for instance, cosmic and spiritual power. Finally, Richard G. Cooke finds that much of the pottery (700-1000) associated with the collection is likely from one site whereas the gold "is more heterogeneous" (115, 145). "Attributing unprovenienced gold artifacts to a specific culture area is considerably more complicated than with pottery," he writes, noting that the collection [acquired in the 1940s] "consists entirely of artifacts found in nonprofessional excavations of mortuary features whose 
goal was the rapid and clandestine acquisition of saleable 'art' objects..." $(145,155)$. Notes and references: about $13 \mathrm{pp}$. [TCK]

El Anatsui: When I Last Wrote to You about Africa. Lisa M. Binder, ed., with contributions by Kwame Anthony Appiah, Olu Oguibe, Chika Okeke-Agulu, and Robert Storr. New York: Museum for African Art, 2010. 170 pp. [Distributed by the University of Washington Press.]

This book is a career-retrospective exhibition catalogue, featuring works by El Anatsui (1944-) from the 1970s to 2009. Born in Ghana, he studied art in the Western tradition at Kumasi, Ghana's College of Art (14-15), and was on the University of Nigeria arts faculty from 1975 to 2009. He uses wood, metal, ceramics, glass, cloth, ink and acrylic, aquatint, etching, and drypoint. He is known for his use of "found" materials such as liquor-bottle caps and tin-can lids, sometimes in "monumental" pieces (for instance, 24-by-30 feet [52]). His "work does belong to the history of modern abstraction," according to Robert Storr (Chicago native, artist, art critic and professor, curator) (52). Kwame Anthony Appiah (a philosophy professor and cultural theorist who grew up in Ghana) finds references in it to traditional Ghanaian cloth designs (6468). In the bottle-cap works, he sees "the beginnings of an examination of the connections between sociability and mass-marketed goods" (73). Anatsui's group exhibitions have included: "Africa Remix: Contemporary Art of a Continent," "Primitivism Revisited: After the End of an Idea," and "Second Lives: Remixing the Ordinary" (154). Notes: about 2 pp. Biography and Exhibition History: 4 pp. Bibliography: 7 pp. [TCK]

Changing Contexts, Shifting Meanings: Transformations of Cultural Traditions in Oceania. Elfriede Hermann, ed. Honolulu: University of Hawai'i Press with the Honolulu Academy of Arts, 2011. 384 pp.

Themes of this edited volume include the role of history in anthropology, scholarly concepts of tradition, the capacity of an object to have different meanings, and the effect of cross-cultural interactions on local meanings. The essays derive from a symposium that was held in 2006 in conjunction with an exhibition, "Life in the Pacific of the 1700s," at the Honolulu Academy of Arts. Now owned by a German university and museum, the exhibition objects were collected during Pacific voyages of Captain James Cook (1728-1779), of the British Royal Navy, from locations including New Zealand, Tonga, Tahiti, Hawai' $i$ and the northwest coast of America (vii). Sections of the book are: "Early Encounters" (essays examine various meanings that the objects have had for Oceanians and Europeans), "Memories" (how Oceanians incorporate the past in the present), "Global and (Trans)local Processes" (how intersecting global and local processes change local meanings), and "Cultural Exchange and Identities" (how cross-cultural exchange shapes identities). Elfriede Hermann and Brigitte Hauser-Schäublin write introductory essays. Peter Hempenstall and Aletta Biersack write concluding essays. Notes and References: about 59 pp. Index: 9 pp. [TCK] 
The Eugene B. Adkins Collection: Selected Works. Jane Ford Aebersold, Christina E. Burke, James Peck, B. Byron Price, W. Jackson Rushing III, Mary Jo Watson, and Mark A. White. Norman: University of Oklahoma Press, with the Fred Jones Jr. Museum of Art and the Philbrook Museum of Art, 2011. 304 pp.

This collection catalogue has two main parts: "Art of the American Southwest" (16-95), featuring European-American artworks from ca. 1837 through at least the 1970s; and "Native American Art" (96-245), showing Native American art and craft works from 1880 to at least the 1990s. Essays in Part I address "Time and Modernity in the Art of the American Southwest," the "character" of the collection, and "The Aesthetic and the Ethnographic: Photography of the American Southwest." Part II essays are: "Influence and Invention: Native American Painting and Sculpture;" "Tradition and Innovation: Native Jewelry, Silverwork, and Fetishes;" "Materials of the Earth and Its People: Baskets and Textiles;" and "Authenticity and Change: Native American Pottery." Collector Eugene B. Adkins (1920-2006) was a Tulsa native with ties to Santa Fe and Taos, New Mexico. His "paternal grandparents were enrolled members of the Cherokee Nation" (3). The Fred Jones Jr. and Philbrook museums, in Norman and Tulsa, Oklahoma, respectively, jointly acquired his collection (more than 3,300 items) in 2008. The book celebrates the opening of new facilities at both locations to display the collection (iv). Notes: 7 pp. Bibliography: 5 pp. Index: 11 pp. [TCK]

Crossroads of Culture: Anthropology Collections at the Denver Museum of Nature and Science. Chip Colwell-Chanthaphonh, Stephen E. Nash, and Steven R. Holen. Boulder: University Press of Colorado, 2010. 224 pp.

In this book, anthropology and archaeology curators of the Denver Museum of Nature and Science (DMNS) "summarize and present" its "cultural treasures," featuring about 125 objects drawn from about 52,000 in the museum's anthropology collection $(37 ; 2-3)$. The first and last chapters review DMNS history, public programs, and current initiatives of its Department of Anthropology. The latter include the "Indigenous Inclusiveness Initiative," given that, "American Indian cultures are at the heart of the anthropology collections" (39-40). Other chapters present objects selected for "beauty, historic value, and cultural meanings" (2), under headings of American ethnology, American archaeology, world ethnology, and world archaeology. Objects include "the first Folsom point [ca. 10,500 BC] found and photographed in place between the ribs of an extinct bison" (103); a ca. 1890 "elaborate Japanese ivory and steel dagger and scabbard" (156); a ca. 1900 "Navajo wool American flag" (52); and artist Eddie Plein's 2007 grill ("dental jewelry" that is "an emblem of success in the hip-hop world"), which spells "DMNS" and is worn by DMNS President George Sparks (99). Notes: 3 pp. Index: 4 pp. [TCK]

From Mud to Jug: The Folk Potters and Pottery of Northeast Georgia. John A. Burrison. Athens: University of Georgia Press, 2010. 180 pp.

This book is "a companion and sequel to" author John A. Burrison's 1983 book, Brothers in Clay: The Story of Georgia Folk Pottery. It covers the history of Northeast Georgia pottery- 
making and its revival in the latter 1900s with new styles and, in 2006, the opening of the Folk Pottery Museum of Northeast Georgia. Inside covers feature "Folk Potters Trail" maps. Chapter titles are: "Folk Pottery: A Handed-on Tradition," "Clay Country: Northeast Georgia," "From Near and Far: Roots of the Tradition," "Clay Clans: Two Pottery Dynasties," "From Mud to Jug: The Production Process," "Staying Alive: Original Uses of Folk Pottery" (pickle, lard, canning, and four-gallon jars; cream pot; syrup and whiskey jugs; five-gallon homebrew crock; pitcher; etc.), "Changing Times: Threats to Functional Folk Pottery," "New Markets: Keeping Their Hands in Clay," "A Home for North Georgia Folk Pottery" [the museum], and "The Living Tradition: North Georgia Folk Pottery Today." The book is generously illustrated with historical and contemporary photographs. Henry Glassie wrote the foreword. Notes: $2 \mathrm{pp}$. Southern folk pottery bibliography: $4 \mathrm{pp}$. Index of potters: $3 \mathrm{pp}$. [TCK]

The Maya World of Communicating Objects: Quadripartite Crosses, Trees, and Stones. Miguel Angel Astor-Aguilera. Albuquerque: University of New Mexico Press, 2010. 352 pp.

In this work, Miguel Angel Astor-Aguilera focuses on the cross shape in Mayan material culture in showing how Mayan meanings from ancient times have survived exposure to Colonial-era (Christian) influences. Arguing that Western cultural context has sometimes distorted understandings of Mayan meanings, he presents data that are intended to serve as "indigenous documentation, although widely scattered, as to the meaning and use of the pre-Europeancontact, quad-cruciform icon. Putting together the information, widely scattered both temporally and spatially throughout the Americas, within an ethnoarchaeological synthesis grounded in social theory has not been easy and will surely prove controversial" (187). Figures include photographs of ancient objects and contemporary Maya as well as object images. Chapter titles include, "What Are Mesoamerican Religions?," "The Living Ancestors: Regeneration in Preclassic and Classic Mesoamerican Imagery," "Postclassic and Colonial Mesoamerica World Views and Mayan Communicating Objects," "Close Encounters with Maya and Roman Catholic Crosses," and "End Discussion: Quadripartitioning and Native American Relational World Views.” Notes: 25 pp. Glossary: 2 pp. References Cited: 49 pp. Index: 6 pp. [TCK]

\section{The National Museums in a Globalised World: A Conference on the Bicentenary of The National Museum of Denmark, Copenhagen May 21-22 2007. Per Kristian Madsen and Lars Jorgensen, eds. Odense: University Press of Southern Denmark, 2010. 220 pp.}

This book presents papers given by national heritage museum administrators from several countries (Denmark, Germany, the Czech Republic, Greece, the U.S., Canada, Australia, New Zealand), addressing how political conditions have affected their institutions. For instance, Germany's museum emphasized military successes through the early 1900s, but under East German rule after World War II it foregrounded workers and peasants. Now, after reunification in 1990, exhibits include ceremonial status symbols, everyday peasant objects, and "a typical room of the back-to-nature Lebensreform movement," forerunner of the 1960s U.S. counterculture movement (19-21). At the Czech museum, staff was cut by more than 100 since 
2002, in the post-socialist era, but programs have expanded (28). In Greece, "the National Archaeological Museum has promoted the basic ideological message of the Modern Greek state" (44). In the U.S., the National Museum of American History is following "recent efforts by national museums such as the National Museum of Australia to consciously reposition themselves as civic spaces for discussion and relinquish their traditional authoritarian roles" (5758). Notes and references: about $6 \mathrm{pp}$. [TCK]

Dynasty and Divinity: Ife Art in Ancient Nigeria. Stephen Robert Frankel, ed. New York: Museum for African Art, 2010. 200 pp. [Distributed by the University of Washington Press.]

This book is the catalogue for a traveling exhibition that the Museum for African Art (New York) and the Fundación Marcelino Botín (Santander, Spain) co-organized in collaboration with Nigeria's National Commission for Museums and Monuments. The Nigerian commission loaned 109 works for the exhibition: objects made by Yoruba people in the West African city-state now known as Ife. Works pictured in the catalogue date from the ninth century (Igbo-Ukwu, east of Ife [148]) to the 20th. Materials used include: terra-cotta, stone (biotite gneiss, granite, granite gneiss), metal (copper or copper-alloy, bronze, iron), and glass (beads). Subjects include: rulers, deities, animals (ram heads, elephant head, hippopotamus head, dog head, goat head, mudfish, crocodile, monkey or ape heads, owls, chameleons), offering box, sword, shield, ceremonial vessels, looped-handle stools, conical heads, scepters, crown, bracelet, bead-making crucibles and anvils, and beads. Many of the sculptures portray a body part, such as head, arm, foot, or torso. Essays by Enid Schildkrout and Henry John Drewal place the artworks in cultural and historical context. Notes: 6 pp. Bibliography: 4 pp. Glossary: 3 pp. [TCK]

\section{Sacred Modern: Faith, Activism, and Aesthetics in the Menil Collection. Pamela G. Smart. Austin: University of Texas Press, 2010. 294 pp.}

Although set in the context of a public U.S. art museum that began as the private collection of wealthy French immigrants (the Menil Collection in Houston, Texas), this book engages with broad themes of museum identity. Among them are: potentially conflicting bases of administrator authority (charisma, collector status, professional training); potential conflicts between aesthetic sensibility and American Association of Museums-approved best practices; a museum's capacity for cultural critique; quantity (number of visitors) vs. quality (visitor experience) as measures of success; how budget shortages affect programming; how placing works in a cultural or an art historical context affects viewer experience; and whether access to art in "aesthetic domains" that are "attentively crafted" can "produce an affecting engagement between persons and objects," thus promoting "Dominique de Menil's project of moral activism-of spiritual and political redemption in the pursuit of an alternative project of modernity" (7). Her goal had been to use art as a means of "rehabilitating the modern," to "create conditions in which faith would have relevance, ... would sustain ongoing humanistic innovation across multiple fields and endeavors" (8-9). Notes: 24 pp. Reference List: 17 pp. Index: 12 pp. [TCK] 


\section{The Archaeology of Clothing and Bodily Adornment in Colonial America. Diana DiPaolo Loren. Gainesville: University Press of Florida, 2010. 140 pp.}

Given that cloth often does not survive the centuries, historical archaeologist Diana DiPaolo Loren promotes in this book the study of dress-related "small finds" (such as buttons and beads) in conjunction with historical, art historical, and anthropological data in order to understand how diverse colonial-era North Americans expressed identity. At a time when NAGPRA has increased museum scholars' awareness of communities of origin, she proposes that this crossdisciplinary approach is a means of moving beyond interpretations that are rooted in collector- or curator-written labels and oriented to the experience of elite European men. "Working with descendant communities has revitalized museum collections, allowing us to more fully understand the ways that people in North America purposefully and creatively constructed their distinct and meaningful identities through clothing and adornment," she writes (94). She argues that the same items had different meanings for people in different conditions. About two-thirds of her 27 images of artifacts and historical pictures are from Harvard University's Peabody Museum of Archaeology and Ethnology, where she is associate curator. References Cited: $21 \mathrm{pp}$. Index: 3 pp. [TCK]

\section{Barn Quilts and the American Quilt Trail Movement. Suzi Parron with Donna Sue Groves. Athens: Ohio University Press, 2012. 240 pp.}

Starting in 2001 in southwestern Ohio, the practice of putting enlarged painted or photographed quilt-block patterns in a series of locations (often walls of old barns) to form a "trail" has spread across the rural/small-town U.S. and into Canada. As discussed here by Suzi Parron, such trails serve on the one hand as tourist attractions that boost local economies, and on the other work to create community and family, local, and regional identity. In an informal, sometimes ideological style (for instance, "[Did quilt-trail travelers] recall the pride of place that existed before the city or suburbia became home?;" and, "The treasure that is a homemade quilt was sacred to both of us" $[4,6])$, Parron draws on interviews with participants, especially originator Donna Sue Groves, to describe how the phenomenon began and rapidly diffused. She does not cite scholarly sources, but her work offers insights into how and why popular culture emerges and into the overlap between concepts of popular and folk culture. The book has about 100 color illustrations. Index: 8 pp. [TCK]

\section{A Companion to Greek Art, vols. I and II. Tyler Jo Smith and Dimitris Plantzos, eds. Malden, MA: Wiley-Blackwell, 2012. 892 pp.}

This edited two-volume set draws from art history, anthropology, and material culture studies as well as classical archaeology in presenting an updated overview of research in ancient (through the first millennium BCE) Greek art studies (8). "Greek art," write the editors, "is no longer as rigidly categorized or as superficially understood as it was in the 18th, 19th, and much of the 20th c." (3). The set is part of the series, "Blackwell Companions to the Ancient World." Volume I has three parts, 20 essays, 12 color plates, six maps, and about 123 black-and-white figures. 
Part I is the introduction. Part II, Forms, Times, and Places (chapters 2 to 14), covers chronology, the larger art categories, working conditions of artisans, and how works by ancient authors remain relevant to the discipline (12-13). Part III, Contacts and Colonies (chapters 15-19), concerns the extent to which "Greek" art occurred elsewhere in the Archaic to Hellenistic periods and also non-Greek influences on Greek art (13). In this part, "several authors use an overtly material culture approach" associated with archaeology, considering hybridity, ethnicity, and historical and social context (13-14). Volume II has two parts, 19 essays (including "Surveying the Scholarship"), about 79 black-and-white photos, a bibliography, and an index. Part IV, Images and Meanings (chapters 20-30), tends to take classical archaeology's "traditional linguistic approach," viewing Greek art as "a codified system of signs" (14). Part V, Greek Art: Ancient to Antique (chapters 31-38), looks at how later cultures shaped the meaning of classicalera Greek art. "Greek art has many faces in museum displays," writes Delia Tzortzaki in chapter 35, titled "Myth and the Ideal in 20th c. Exhibitions of Classical Art" (667). Part V also has an essay on "The Cultural Property Debate" and one that considers research in the age of the Internet. Bibliography: 94 pp. Index: 20 pp. [TCK]

Marajó: Ancient Ceramics from the Mouth of the Amazon. Margaret YoungSánchez and Denise P. Schaan. Denver, CO: Mayer Center for Pre-Columbian and Spanish Colonial Art, Denver Art Museum, 2011. 88 pp. [Distributed by the University of Oklahoma Press.]

This book is the catalogue for a Denver Art Museum exhibition, "the first in the United States to focus on ancient Amazonian art" (5). Co-author and exhibition curator Margaret Young-Sánchez argues that it shows that the Marajó Island culture (in present-day Brazil) was not "the impoverished cultural descendant of Andean high civilizations," but "one of the pre-Columbian world's most sophisticated artistic traditions, now known almost exclusively from ceramics" (58, 57). Most objects date to CE 400-1300, a few to CE 1200-1600 (34, 67). Included are jars, stools, pubic covers, handled pots, phallic figurines, bowls, plates, funerary urns (some with snake symbolism), and a cup, pedestal plate, double-spouted bottle, and turtle figurine. Photographs show the objects and present-day Marajó. On a few, object designs are outlined in black. Two document a 1915 archaeological expedition (13, 64). Young-Sánchez's essay, "Marajó and Its Cultural Context," includes a section on Technology and Production. Co-author Denise P. Schaan's essay, "Venerating Ancestors: The Symbolics of Marajoara Social Life," includes sections on The Political Economy of Marajoara Societies, Funerary Practices and Social Status, and The Ceramic Symbolic Language. References: 4 pp. [TCK]

Inuit Prints: Japanese Inspiration: Early Printmaking in the Canadian Arctic. Norman Vorano, with an essay by Asato Ikeda and Ming Tiampo, and contributions from Kananginak Pootoogook. Gatineau, Quebec: Canadian Museum of Civilization, 2011. 100 pp.

This book is the catalogue for a traveling exhibition that the Canadian Museum of Civilization produced, and that opened in Tokyo. It examines the cultural and artistic exchange that occurred when five Inuit men adopted and adapted a woodcut-printmaking practice, starting in 1959, that 
a white Canadian taught them after having studied it in Japan. It shows works by Japanese and Inuit artists, and by mediator James Houston (1921-2005), who was an artist and a civil servant. It contrasts tools, techniques, and subjects, and includes comments from artists. Providing art historical and anthropological context, it notes that craft production "had become an important source of income for Inuit" in the Eastern Arctic as they modernized their lifestyle $(4,6)$; that Houston likely had seen printmaking, in contrast to stone sculpture, basketry, and animal-skin pictures, as a potentially income-boosting "graphic art format that could better fit within the existing regimes of value in the fine art world" (3-4); and that he also had learned in Japan "a recipe for exploiting the discursive space opened by modernist primitivism" (20). 143 footnotes. [TCK]

\section{Representing Africa in American Art Museums: A Century of Collecting and Display. Kathleen Bickford Berzock and Christa Clarke, eds. Seattle: University of Washington Press, 2011. 320 pp.}

This edited volume uses histories of particular prominent collections to show how ideas of African art have changed since it "first entered American art museums between 1880 and the 1920 s, often as a component of "primitive art"" (6). Current views, on the other hand, are "fostered by the multiculturalism and the identity politics of the 1980s and 1990s" (12). The editors find that evidence presented here suggests that the way that the museums have treated African objects "ultimately reveals more about Western aesthetic perceptions and museum practices than about African art itself" (12). Featured institutions are: Cincinnati Art Museum, Hampton University Museum (historically African American, Virginia), Brooklyn Museum (New York City), Barnes Foundation (Merion, a Philadelphia suburb), Cleveland Museum of Art, Museum of Primitive Art (founded in 1954 in New York City; closed in 1974 and collections moved to the Metropolitan Museum of Art), Art Institute of Chicago, Indiana University Art Museum, UCLA's Fowler Museum, University of Iowa Museum of Art (Stanley Collection), Seattle Art Museum, Menil Collection of African Art (Houston), and the National Museum of African Art (Washington, DC). References and notes: about 80 pp. [TCK]

\section{Textile Economies: Power and Value from the Local to the Transnational. Walter E. Little and Patricia A. McAnany, eds. Lanham, MD: AltaMira Press, 2011. 342 pp.}

This volume presents papers from the Society of Economic Anthropology's meeting in 2009, its 29th year, titled "Weaving Across Time and Space: the Political Economy of Textiles" (xi). The 15 chapters focus on ancient and contemporary groups in places that include Morocco, Senegal, Madagascar, the Cook Islands, Cambodia, Turkey, the Philippines, Indonesia, India, Italy, the Andes, Guatemala, and the southwestern U.S. The book has an introduction and three parts: "Creativity and Value," "The Power of Cloth and the Sanctity of Power," and "(Re)invented Traditions in Transnational Context." It has about 60 illustrations, all in black and white, and three tables. Citing Annette B. Weiner and Jane Schneider's foundational work, Cloth and Human Experience (Washington, Smithsonian Institution Press, 1989), the editors note in the introduction, "The design plasticity of the textile medium means that woven items have always reflected and thus created group identity. Issues of identity... emerge as a central feature of many 
of the contemporary studies presented here" (xxiii-xxiv). In addition, "We are shown the dark side of transnational economies and heritage tourism and, in the process, come to better understand the factors that underlie textile production" (xxiv). Notes and bibliographies: about $62 \mathrm{pp} .[\mathrm{TCK}]$

\section{Public Properties: Museums in Imperial Japan. Noriko Aso. Durham, NC: Duke University Press, 2014. 301 pp.}

In this book, historian Noriko Aso analyzes the role of museums during the imperial era of Japan (1880s-1945) and how they became sites of expression and negotiation of imperial identity, locations in which the relationship of the state to society was contested, and where various publics were fostered. Aso's work critically examines the history of public exhibitions in the Tokugawa period (1600-1867) and the marked shift to the imperial state ownership, which established frameworks for cataloging and recognizing cultural properties and heritage. In the chapter on colonial museums, she examines how the Government-General Museum of Taiwan became a site of intensive research of Taiwan's natural and cultural properties as well as assimilatory outreach, and the Yi Royal Family Museum in Korea ultimately served as a location to "subordinate and control Korean sovereignty" (113). Aso explores how private-sector museums such Ōhara Magosaburô's Ōhara Museum of Art, Shibusawa Keizo's museum of folk economics, and Yanagi Muneyoshi's Japan Folk Crafts Museum worked to offer access as well as counter-narratives to that of the elite aesthetic, then turns to how department stores fostered broader conceptions of nation and publics and maintained close, if sometimes strained, relationships with other state institutions. Aso concludes with the changes to museums in Japan in the post-imperial era. Notes: 55 pages. Bibliography 23 pages. [KS]

http://dx.doi.org/10.14434/mar.v8i1.12828 